Article

\title{
Effect of Modified Tapioca Starch on Mechanical, Thermal, and Morphological Properties of PBS Blends for Food Packaging
}

\author{
Rafiqah S. Ayu ${ }^{1}{ }^{(0)}$, Abdan Khalina ${ }^{2, *}$, Ahmad Saffian Harmaen ${ }^{3}{ }^{(0)}$, Khairul Zaman ${ }^{4}$, \\ Mohammad Jawaid ${ }^{1}$ (D) and Ching Hao Lee ${ }^{1, *(D)}$ \\ 1 Laboratory of Biocomposite Technology, Institute of Tropical Forestry and Forest Products (INTROP), \\ Universiti Putra Malaysia, Serdang 43400 UPM, Selangor, Malaysia; ayu.rafiqah@yahoo.com (R.S.A.); \\ jawaid@upm.edu.my (M.J.) \\ 2 Laboratory of Biopolymer and Derivatives, Institute of Tropical Forestry and Forest Products (INTROP), \\ Universiti Putra Malaysia, Serdang 43400 UPM, Selangor, Malaysia \\ 3 Institute of Tropical Forestry and Forest Products (INTROP), Universiti Putra Malaysia, \\ Serdang 43400 UPM, Selangor, Malaysia; harmaen@upm.edu.my \\ 4 Polycomposite Sdn Bhd, Taman Kajang Sentral, Kajang 43000, Selangor, Malaysia; dr.khairulz@gmail.com \\ * Correspondence: khalina@upm.edu.my (A.K.); leechinghao@upm.edu.my (C.H.L.); \\ Tel.: +603-8946-6420 (A.K.); +601-6659-5851 (C.H.L.)
}

Received: 16 September 2018; Accepted: 18 October 2018; Published: 25 October 2018

check for updates

\begin{abstract}
In this study, polybutylene succinate (PBS) was blended with five types of modified tapioca starch to investigate the effect of modified tapioca starch in PBS blends for food packaging by identifying its properties. Tensile and flexural properties of blends found deteriorated for insertion of starch. This is due to poor interface, higher void contents and hydrolytic degradation of hydrophilic starch. FTIR results show all starch/PBS blends are found with footprints of starch except $\mathrm{OH}$ stretching vibration which is absent in $\mathrm{B} 40$ blends. Besides, Broad $\mathrm{O}-\mathrm{H}$ absorption in all specimens show that these are hydrogen bonded molecules and no free $\mathrm{O}-\mathrm{H}$ bonding was found. SEM testing shows good interfacial bonding between PBS and starch except E40 blends. Therefore, poor results of E40 blends was expected. In TGA, a slightly weight loss found between 80 to $100{ }^{\circ} \mathrm{C}$ due to free water removal. Apart from this, insertion of all types of starch reduces thermal stability of blend. However, high crystallinity of starch/PBS blend observed better thermal stability but lower char yield. Starch $A$ and $B$ blends are suggested to be used as food wrap and food container materials while starch $\mathrm{D}$ blend is suitable for grocery plastic bags according to observed results.
\end{abstract}

Keywords: polybutylene succinate; tapioca starch; mechanical properties; scanning electron microscopy; TGA

\section{Introduction}

Food packaging is a frequent topic on global challenge as plastic packaging has largest demand especially developed countries that reliance on processed foods [1]. Conventional plastic packaging is a problematic material as it has good oxidation resistance, but creates landfill pollution [2]. Packaging materials that are made by synthetic polymers are widely used, even though they take a long time to decompose naturally, causing waste-product accumulation [3-5]. Therefore, it is necessary to substitute current packaging materials with biodegradable ones. The plastics used in food wrap and food containers may contact the food, therefore, edible plastic is highly recommended [6].

Starch is one of the most abundant low-cost natural resources and one of the important bioresources used in the food industry, such as paper, thickeners, and gelling agents [7]. Starch has good physical, 
mechanical, and barrier properties that have the potential to become active films. Nonetheless, limitations of starch are concerning for its hydrophilic nature and lack of antioxidant ability [8]. Therefore, modified starches are known as "environmentally friendly" materials and commonly used as stabilizers, viscosifying agent, coatings, and thickeners [9]. Modified starch is a chemically-altered food ingredient. The purpose of modifying the starch is to eliminate gluten content in starch and to improve its ability to keep the texture and structure of the food. The use of modified starch could reduce the processing time for compound formation. Proteins that exist in starch form networks and assist the enhanced plasticity and elasticity properties of the materials when preparing biopolymer-based packaging materials [10].

The use of tapioca starch as bioplastics in industrial food packaging is still limited due to its hydrophilic nature, brittleness, thermal instability, as well as high production cost and the large area of land needed to produce bioplastic [11]. Several technologies were found to improve the performance of starch bioplastics, such as plasticization, chemical modification, or blending with polyesters [12].

Attention to aliphatic polyester has greatly increased in recent years with regards to promising sustainable and biodegradable material prospects. Polybutylene succinate (PBS) is one of the biodegradable aliphatic polyesters that has been produced using petroleum-based monomers [13-18]. PBS polymer can be obtained from the polycondensation process of 1,4-butanediol and succinic acid [19]. PBS has virtuous physical and mechanical properties, good processability, and biodegradability for a wide range of applications [20]. PBS polymer is more stable under flowing nitrogen at temperatures below $220^{\circ} \mathrm{C}$ with the rate of mass loss reaching a maximum at $390^{\circ} \mathrm{C}$, showing it has better thermal stability than PLA polymer (with a maximum at $365-385^{\circ} \mathrm{C}$ ) [21]. Additionally, the flexibility of PBS backbone and the presence of readily hydrolysable ester bonds, which are prone to catalytic degradation by microorganisms or enzymes, causing rapid degradation process for PBS polymer.

Starch/polyester blended plastics are meant to improve processing properties and better strength. Previous studies investigated two types of starch blended with PBS polymer [22]. It was found that higher starch content resulted in lower tensile strength, melt flow index, and higher moisture absorption for both starch/PBS blends. Moreover, conversion of starch into thermoplastic starch must be done by using glycerol before it blends with the PBS polymer $[23,24]$. This is totally unacceptable for commercialized use due to the longer production time and extra costs needed to be invested. Furthermore, glycerol content is another factor that influences performance. Higher glycerol content will shift the blends toward brittle region, yet it makes process easily, higher crystallinity content.

Modified tapioca starch can mix directly with PBS without undergoing the gelatanization process. It will fill the gap of knowledge by reducing the process period, as well as the production cost. In this study, the properties of modified tapioca starches/PBS blends will be studied and, most importantly, it is done by a simple fabrication method. This shall attract interest from researchers and industry, especially in food packaging. The PBS polymer simply blends with five different types of modified tapioca starch by using a rotating internal mixer and a hot press.

\section{Experimental}

\subsection{Materials}

PBS in the form of pallets were bought from PTT Public Company Limited in Bangkok, Thailand. The density of PBS is $1.26 \mathrm{~g} / \mathrm{cm}^{3}$. Tapioca starch in the form of powder was obtained from PT Starch Solution in Karawang, Indonesia. It has five modified starch grades (A, B, C, D, E) with different properties. Table 1 shows its properties, as provided by supplier. 
Table 1. Properties of five starches.

\begin{tabular}{cccccc}
\hline Properties & $\begin{array}{c}\text { Starch } \\
\text { Type A }\end{array}$ & $\begin{array}{c}\text { Starch } \\
\text { Type B }\end{array}$ & $\begin{array}{c}\text { Starch } \\
\text { Type C }\end{array}$ & $\begin{array}{c}\text { Starch } \\
\text { Type D }\end{array}$ & $\begin{array}{c}\text { Starch } \\
\text { Type E }\end{array}$ \\
\hline Moisture, \% & 11.1 & 8.1 & 7.2 & 8.6 & 11.2 \\
Bulk Density, g/cm ${ }^{3}$ & 0.63 & 0.62 & 0.59 & 0.53 & 0.54 \\
Beginning of gelatanization $\left(T_{\mathrm{g}}\right),{ }^{\circ} \mathrm{C}$ & 51 & 45.2 & 44.9 & 60.3 & 69.4 \\
Maximum Brabender viscosity, BU & 1291 & 228 & 405 & 750 & 717 \\
Viscosity, Cp & 5.5 & 6.5 & 6.3 & 5.7 & 6.1 \\
\hline
\end{tabular}

\subsection{PBS and Starch Preparation}

The PBS pallets are first dried in an oven at $80{ }^{\circ} \mathrm{C}$ to prevent excessive hydrolysis which can compromise the physical properties of the polymer. After that, PBS was melted in a counter-rotating internal mixer (Brabender, UPM, Serdang, Malaysia) at $115^{\circ} \mathrm{C}$ with rotation of $60 \mathrm{RPM}$. Subsequently, modified tapioca starch $(\mathrm{A} / \mathrm{B} / \mathrm{C} / \mathrm{D} / \mathrm{E})$ was loaded into the mixer and blended for another $10 \mathrm{~min}$ until a homogenous compound was achieved. The compound was crushed into small pieces by using crusher machine (UPM, Serdang, Malaysia) before being pressed. Next, the compound was molded by using a hot press at $115^{\circ} \mathrm{C}$ for $4 \mathrm{~min}$ and left to cool for another $3 \mathrm{~min}$. Then, specimens were cut into shapes according to specific characterization testing. Five specimens from every combinations will be tested for each conducted testing. The naming of specimens was done according to the type and the volume contents of starch in the PBS blends; for example, A40 represents $40 \mathrm{wt} \%$ of type A starch blended in PBS polymer. There are a total of 15 specimens constructed by five types of starch (A, B, C, $\mathrm{D}$, and $\mathrm{E})$ and three volume contents of starch $(40,50$, and $60 \mathrm{wt} \%)$ in PBS polymer blends.

\subsection{Characterization}

\subsubsection{Mechanical Properties}

The tensile test was carried out according to ASTM D638-14 test method at a strain rate $50 \mathrm{~mm} / \mathrm{min}$ using an Instron universal tester (UPM, Serdang, Malaysia) under room temperature. For flexural testing was carried out under room temperature following the standard ASTM 790-17 standard. Optimum loadings of specimens were selected to conduct the following characterizations.

\subsubsection{Fourier Transform Infrared Spectroscopy}

Fourier transform infrared spectroscopy (FTIR) was performed using Perkin Elmer 1600 infrared spectrometer (UPM, Serdang, Malaysia) to conduct in the wavenumber range of 500-4000 $\mathrm{cm}^{-1}$ with $4 \mathrm{~cm}^{-1}$ resolution. The positions of significant transmittance peaks at a wavenumber was tracked by using Nicolet software.

\subsubsection{Morphological Analysis}

Morphology of the samples was observed using Hitachi S-3400N scanning electron microscope (SEM, UPM, Serdang, Malaysia) equipped with energy dispersive X-ray (EDX, UPM, Serdang, Malaysia) under an accelerating voltage of $15 \mathrm{kV}$. The samples were gold sputtered before observation to avoid the charging effect.

\subsubsection{Thermal Analysis}

The thermal stability of the samples was characterized using a TA Instruments Q500 thermogravimetric analyzer, TGA, (UPM, Serdang, Malaysia). About $6 \mathrm{mg}$ of sample was scanned from 30 to $900{ }^{\circ} \mathrm{C}$ at a heating rate of $20^{\circ} \mathrm{C} \cdot \mathrm{min}^{-1}$ under nitrogen gas atmosphere. 


\section{Results and Discussion}

\subsection{Mechanical Properties}

Mechanical properties of starch/PBS blends are presented in Table 2. Tensile strength and tensile modulus of the blends starch were compared in Figure 1. It is clearly shown that tensile stress for all types of starch were decreased as the volume content of starch increased. This could be explained by the main phase changing from PBS (comparatively flexible) to starch (comparatively rigid), reporting better rigidity, but lower strength and extensibility [22,25]. Additionally, low dispersion of starch in PBS resulted in the occurrence of stress concentration spots. Hence, deteriorated tensile strength is observed. In return, the tensile modulus is remarkably increased [26].

Apart from this, increasing starch content produces more voids, resulting in a weakening structure of the blends due to poorer interfacial bonding between PBS and starch. Starch E/PBS blends show the lowest average tensile values because of high chain branches of the amylopectin component richly found in starch E blends, which will detangled easily [16]. On the other hand, other starch blends showing better tensile strength were contributed from high crystallinity amylose content as stated in a previous work [22]. A high linear amylose structure in starch provided effective entanglement, which improved the tensile strength, and starch D shows the highest amylose contents with the highest tensile strength.

Flexural strength and flexural modulus of starch/PBS blends are given in Table 2 and its corresponding data were plotted in Figure 2. Overall, incrementing starch volume contents have reduced flexural strength of the blends. This could refer to the poor interface between the polymer and starch fillers, rendering the load transferring mechanism ineffective. As the loading of the hydrophilic starch increases, more hydroxyl groups induced hydrolytic degradation, ending in further deterioration of the flexural strength [15]. The lowest flexural strength found for the starch E blend was synchronized with other characterization testing.

Type D starch molecules tend to slip past each other under bending, leading to lower flexural modulus even though good tensile strength is observed [27]. On the other hand, $60 \mathrm{wt} \%$ of starch B and $\mathrm{D}$ in blends exceeded the optimum volume as more starch fillers slip away under the bending mechanism, indicating optimum filler insertion should be less than $50 \mathrm{wt} \%$ for starch B and D. In conclusion, the following characterization will be conducted on $40 \mathrm{wt} \%$ specimens due to budget constraints.

Table 2. Mechanical properties modified tapioca starch/PBS blends.

\begin{tabular}{ccccc}
\hline Specimen & $\begin{array}{c}\text { Tensile Strength } \\
\mathbf{( M P a}\end{array}$ & $\begin{array}{c}\text { Tensile Modulus } \\
\mathbf{( M P a )}\end{array}$ & $\begin{array}{c}\text { Flexural Strength } \\
\mathbf{( M P a}\end{array}$ & $\begin{array}{c}\text { Flexural Modulus } \\
\mathbf{( M P a})\end{array}$ \\
\hline A40 & $17.59 \pm 1.25$ & $1082.24 \pm 228.21$ & $50.41 \pm 4.20$ & $2137.70 \pm 260.59$ \\
A50 & $13.49 \pm 0.60$ & $2040.13 \pm 73.86$ & $36.87 \pm 1.06$ & $2252.84 \pm 181.69$ \\
A60 & $12.57 \pm 0.72$ & $2655.27 \pm 148.21$ & $29.61 \pm 2.77$ & $3188.48 \pm 323.42$ \\
B40 & $16.59 \pm 0.17$ & $1284.82 \pm 58.27$ & $45.99 \pm 1.70$ & $1569.25 \pm 122.82$ \\
B50 & $12.89 \pm 0.330$ & $1945.16 \pm 52.01$ & $37.67 \pm 1.69$ & $2031.28 \pm 176.94$ \\
B60 & $11.32 \pm 0.51$ & $2142.13 \pm 54.26$ & $21.39 \pm 1.64$ & $1265.52 \pm 69.70$ \\
C40 & $16.02 \pm 0.11$ & $821.46 \pm 42.64$ & $19.02 \pm 0.64$ & $378.690 \pm 42.30$ \\
C50 & $14.97 \pm 1.31$ & $915.33 \pm 32.98$ & $17.58 \pm 0.61$ & $655.896 \pm 14.63$ \\
C60 & $13.76 \pm 0.93$ & $1042.12 \pm 17.42$ & $12.87 \pm 1.05$ & $727.07 \pm 55.79$ \\
D40 & $18.13 \pm 0.64$ & $586.48 \pm 40.39$ & $16.86 \pm 1.25$ & $397.87 \pm 22.01$ \\
D50 & $17.79 \pm 0.51$ & $736.21 \pm 10.12$ & $17.49 \pm 1.24$ & $562.11 \pm 40.65$ \\
D60 & $13.11 \pm 0.42$ & $764.39 \pm 15.14$ & $15.46 \pm 1.63$ & $395.57 \pm 53.15$ \\
E40 & $14.98 \pm 1.23$ & $534.77 \pm 32.47$ & $12.43 \pm 0.40$ & $663.304 \pm 21.69$ \\
E50 & $14.03 \pm 1.08$ & $745.18 \pm 65.94$ & $16.12 \pm 0.62$ & $594.282 \pm 42.28$ \\
E60 & $11.95 \pm 0.84$ & $885.01 \pm 70.50$ & $12.40 \pm 1.35$ & $770.02 \pm 53.62$ \\
\hline
\end{tabular}




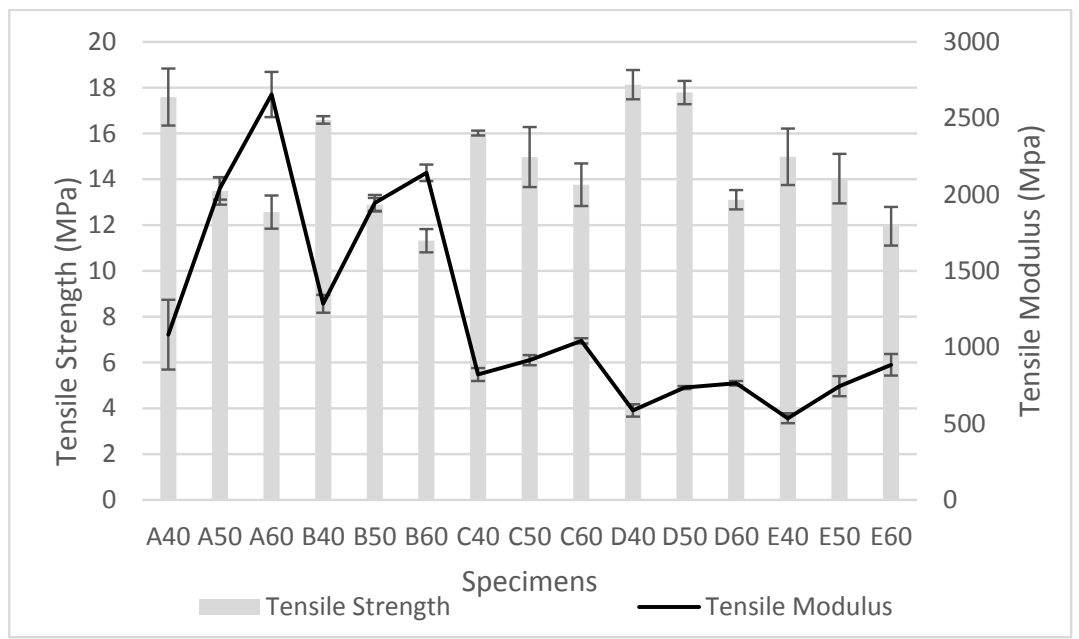

Figure 1. Tensile strength and tensile modulus of starch/PBS blends.

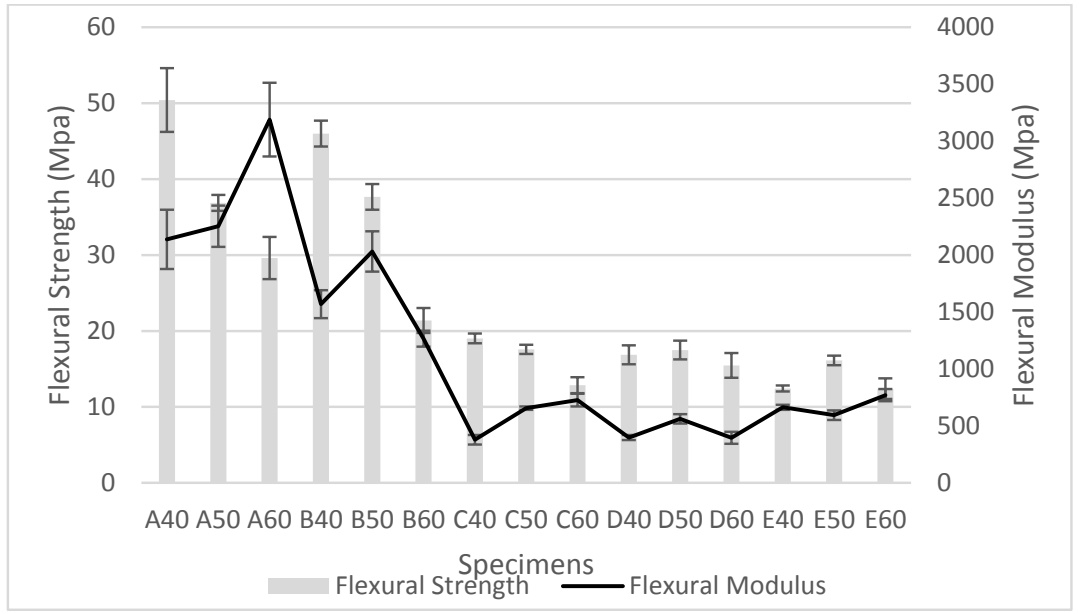

Figure 2. Flexural strength and flexural modulus of starch/PBS blends.

\subsection{FTIR Analysis}

To study the interaction between starch and PBS polymer, FTIR spectra of the specimens were evaluated. Figure 3. shows the FTIR spectra of $40 \mathrm{wt} \%$ starch/BS blends. It is clearly visible at the starch fingerprints region of 800 to $1500 \mathrm{~cm}^{-1}$, that the spectral characteristic of all types of modified starch are similar. All starch/PBS blends have found footprints of starch which consist of alkene, esters, aromatics, ketone, and alcohol, with different oxygen-containing functional groups, e.g., $\mathrm{OH}$ $\left(3400-3200 \mathrm{~cm}^{-1}\right), \mathrm{C}=\mathrm{O}\left(1765-1715 \mathrm{~cm}^{-1}\right)$, and $\mathrm{C}-\mathrm{O}-(\mathrm{H})\left(1050 \mathrm{~cm}^{-1}\right)$ excepted $\mathrm{OH}$ stretching vibration not found in sample B40. The $\mathrm{O}-\mathrm{H}$ stretching mode is due to the hydrolytic effect of starch on the polymeric matrix, providing the formation of hydrogen bonded alcohol end groups [28]. Broad $\mathrm{O}-\mathrm{H}$ absorption in all specimens shows that these are hydrogen-bonded molecules and no free $\mathrm{O}-\mathrm{H}$ bonding was found. The presence of bonded hydrogen bonding also indicate stretching of water molecules strongly coupled to the structure of the starch and PBS, and the types of starch determined the strength of hydrogen bonds [29].

The band at $1156 \mathrm{~cm}^{-1}$ was associated with ordered structures of starch [30]. Amorphous regions of starch are mainly formed by internal long chains of amylose and amylopectin. In addition, amylose was found to be more concentrated at the periphery than in the core of the granule [31]. All spectra in the region below $800 \mathrm{~cm}^{-1}$ exhibiting complex vibrational modes due to the skeletal mode vibrations of the pyranose ring in the glucose unit. 
PBS is a condensation biopolymer exhibiting hydroxyl and carboxyl terminated chains with the relevant end group content that is dependent on polymerization conditions [21]. Meanwhile, the region between 2800 and $3000 \mathrm{~cm}^{-1}$ represent the $\mathrm{C}-\mathrm{H}$ stretch region. The peak in the $1710-1720 \mathrm{~cm}^{-1}$ region indicates the presence of $\mathrm{C}=\mathrm{O}$ bonds in the presence of polybutylene succinate [32]. The region between 900 and $1149 \mathrm{~cm}^{-1}$ is associated with the presence of $\mathrm{C}-\mathrm{O}$ bond stretching [33]. Additionally, the band located at $1153 \mathrm{~cm}^{-1}$ was associated with $\mathrm{C}-\mathrm{O}$ bond flexion of the hydroxyl groups [34]. All spectra in the specific region were justified by the presence of PBS and starch materials in the specimen that was tested.

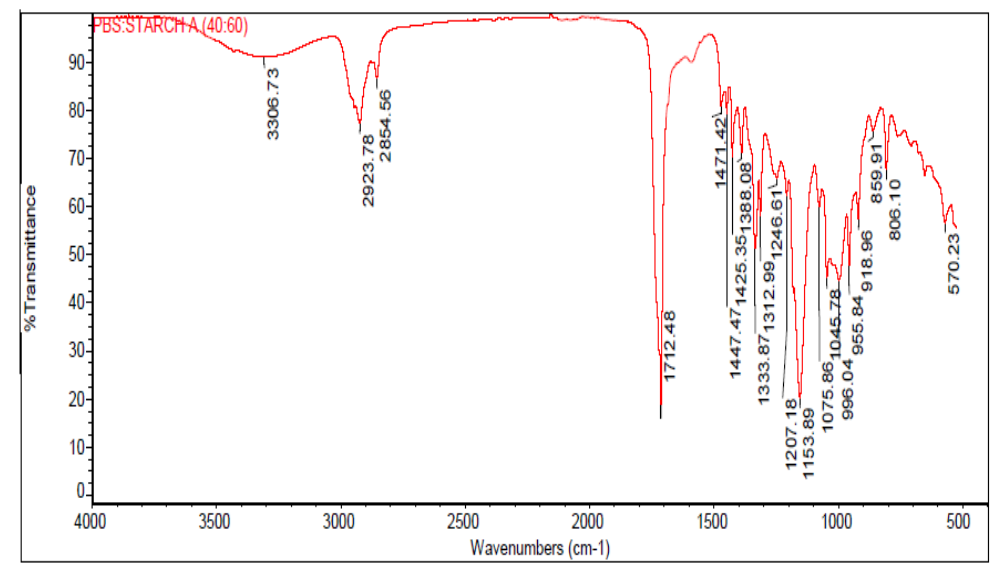

(a)

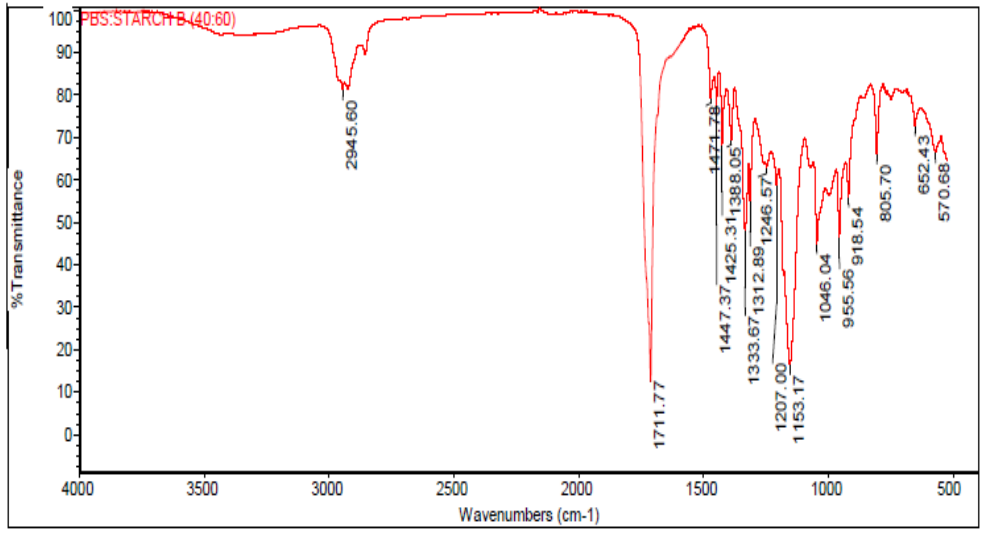

(b)

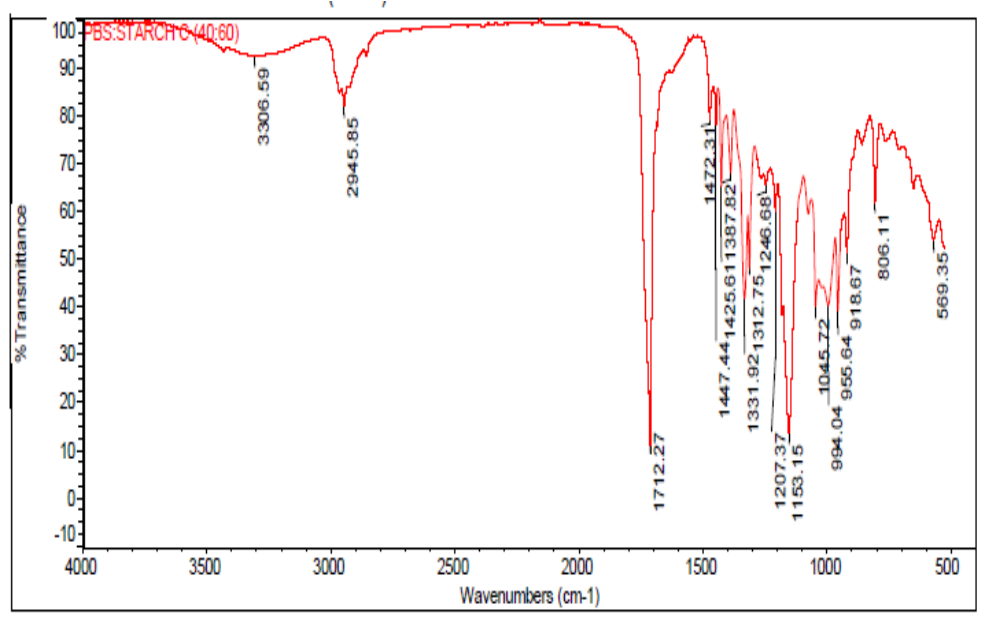

(c)

Figure 3. Cont. 


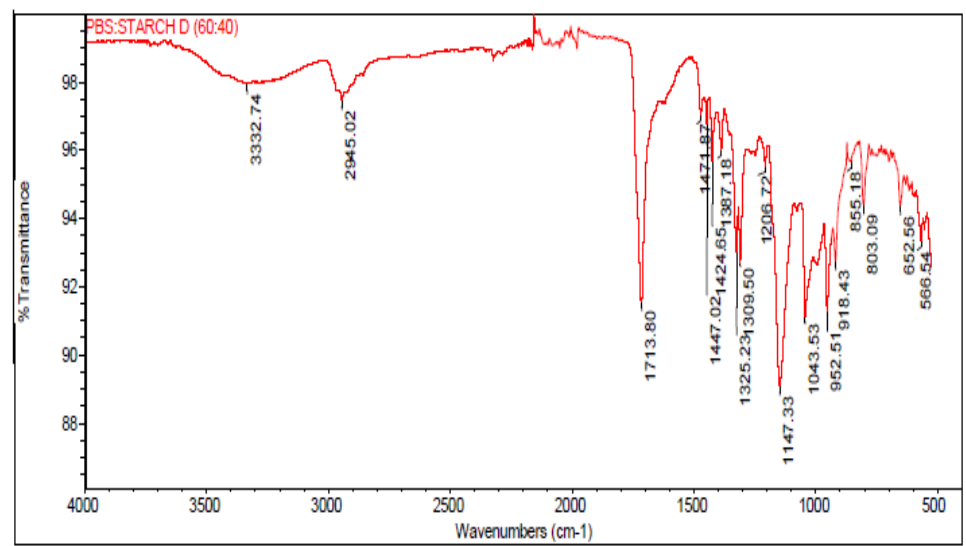

(d)

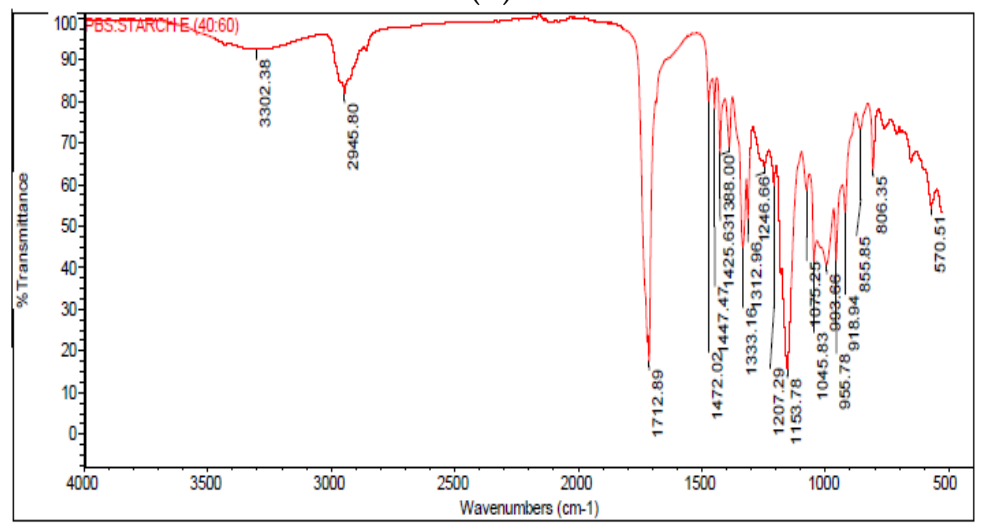

(e)

Figure 3. FTIR spectra of PBS blends with (a) Starch A; (b) Starch B; (c) Starch C; (d) Starch D; and (e) Starch E.

\subsection{Morphology Analysis of Starch/PBS Blends}

Mechanical properties are directly related to the morphology of composites. Cross-section cuts of the specimen variations were performed to explore the effects of different types of modified starches on the internal structure by SEM analysis (Figure 4). Figure 4a shows smooth and regular surfaces for the PBS polymer. Meanwhile, the surface for starch/PBS blends shows differently with various types of starch. The presence of modified tapioca starch resulted in a spherical shape embedded on the PBS surface [35]. Modified tapioca starch has a wider particle size distribution, toward the smaller diameters, as compared to its native starch. Starch A, B, C, and D blends show good interface with PBS compared with other types of starch. Other than that, they show homogenous morphology, resulting in strong interaction between starch and PBS polymer, further resulting in promising performance. This analysis was justified by the mechanical properties results. For Starch E, the image shows weak bonding between PBS and starch, therefore indicating easy debonding during fracture. Starch particles not well dispersed on the PBS surface cause weak bonding between the starch and PBS, which corresponds well with the results of tensile testing. A rough surface (Figure $4 \mathrm{f}$ ) was discovered with some small holes and faults which are similar to previous studies of $40 \mathrm{wt} \%$ and above of PBS content $[22,36,37]$. 


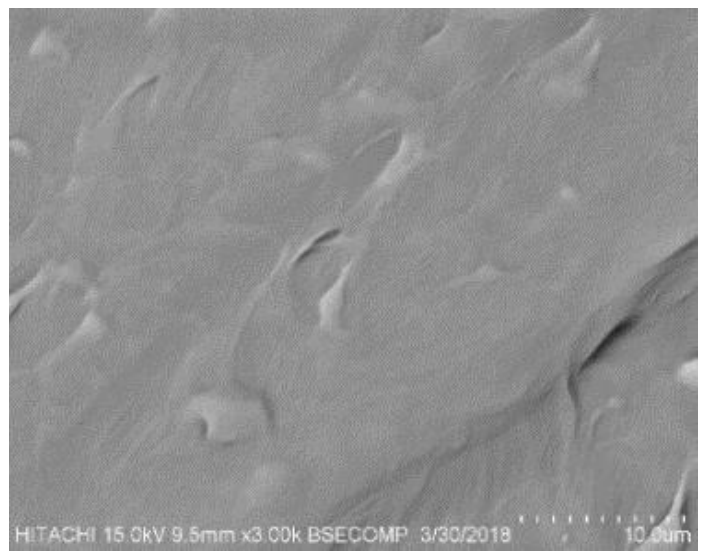

(a)

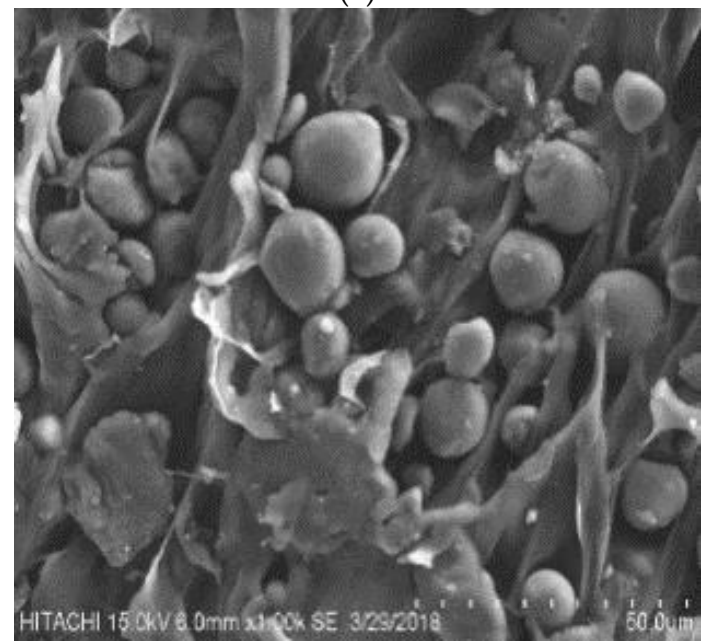

(c)

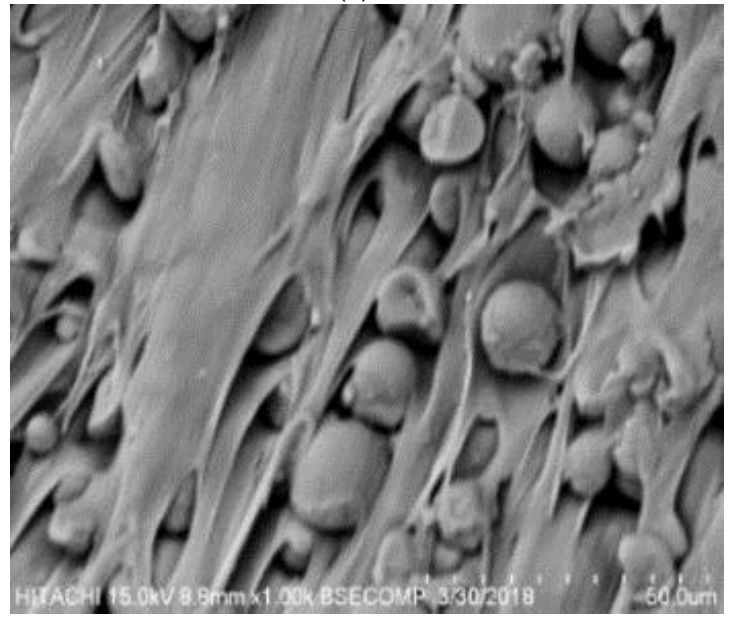

(e)

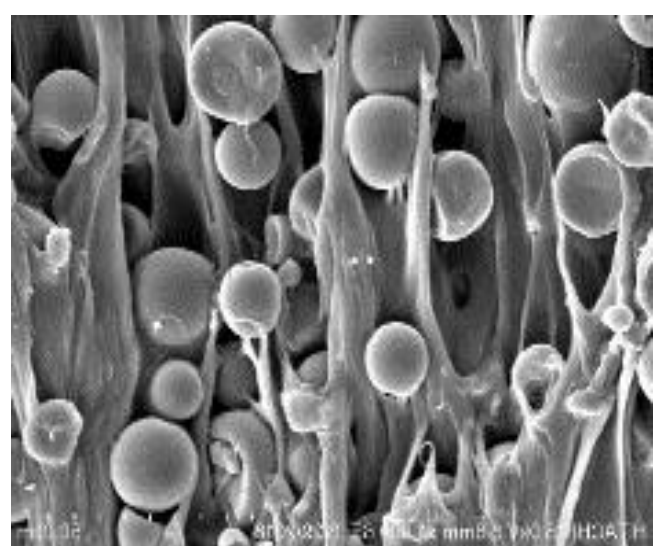

(b)

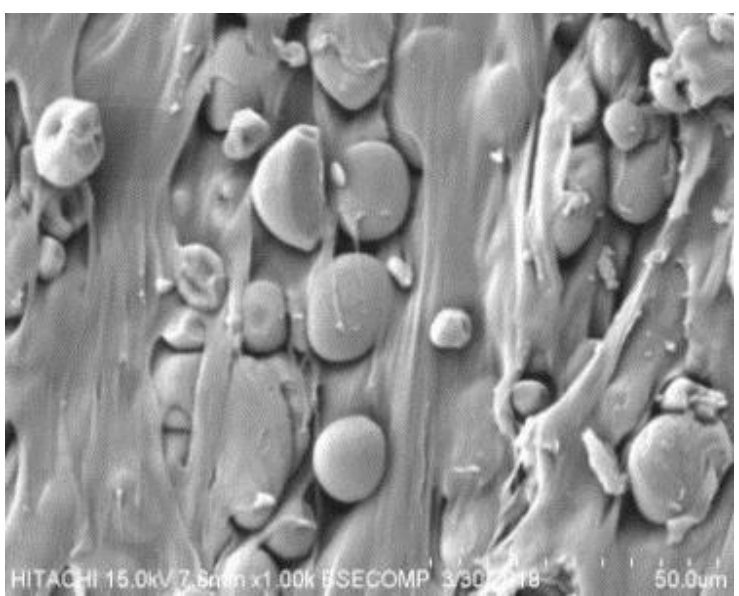

(d)

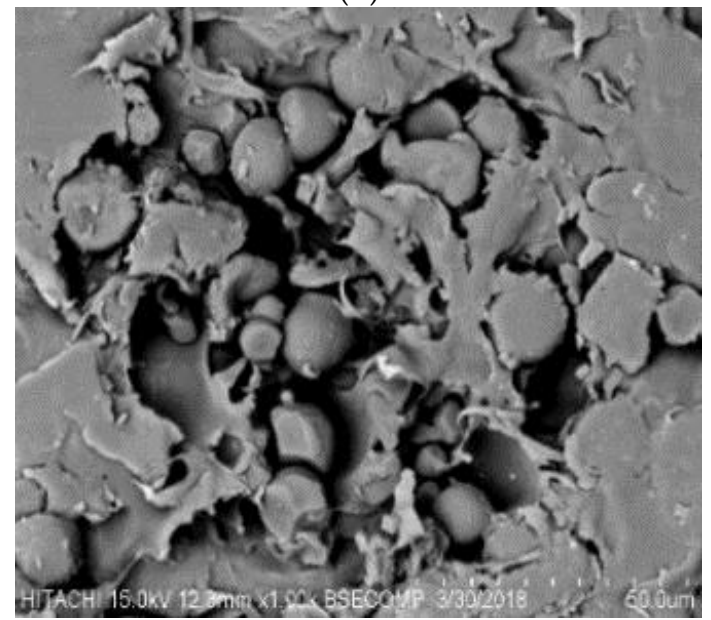

(f)

Figure 4. SEM analysis of (a) pure PBS; (b) A40; (c) B40; (d) C40; (e) D40; and (f) E40.

\subsection{Thermal Properties}

Thermal degradation of starch/PBS blends have been studied by TGA testing. Figure 5 shows the mass lost in every stage with peak temperature, as well as the residual mass at $600{ }^{\circ} \mathrm{C}$. A slight weight loss was found between 80 and $100{ }^{\circ} \mathrm{C}$ for every specimen, reported due to water removal as starches have a high tendency to absorb moisture [38,39]. Thermal degradation of starch/PBS blends involved complex reactions, such as breakage of $\mathrm{C}-\mathrm{C}, \mathrm{C}-\mathrm{H}$, and $\mathrm{C}-\mathrm{O}$ bonds, which showed in FTIR testing. The sharp transition occurring over a temperature range of $220-270{ }^{\circ} \mathrm{C}$ represents the decomposition 
of polysaccharide in starch/PBS blends. A transition which commenced at the onset temperature of about $356-372{ }^{\circ} \mathrm{C}$ can be attributed to the decomposition of the PBS. It is a highly thermally stable polyester (temperature for $5 \%$ weight loss $=338.14{ }^{\circ} \mathrm{C}$, residual mass at $600{ }^{\circ} \mathrm{C}=0.39 \%$ ), therefore, the second mass loss reported belongs to the thermal degradation of PBS polymer. On the other hand, the first mass loss was the result of the degradation of starch [40].

Nonetheless, the insertion of all types of starch had observed lower onset temperature. This is due to the degradation of the blend beginning at the surface of the filler, which, in this study, referred to the starch. However, the main components in the starch are composed of high-crystallinity amylose and highly-branched amylopectin [41]. The higher the amylose content, the better the decomposition temperature. High crystallinity of starch (starch type A, B, C, and D, referred to good strength value) increase the thermal stability, but lowered the char yield as agreed by previous research [42,43]. Among all starch/PBS blend, the Starch D blend has the highest strength value, but opposed in the thermal decomposition temperature. This is consistent with the finding of Maubane (2017), high amylose content starch blends have the highest strength, but moderate thermal stability [16]. Additionally, better thermal stability was due to the low amount of remaining hydroxyl groups in the starch molecules after modification [44]. In this regard, the remaining weight at temperatures above $430{ }^{\circ} \mathrm{C}$ could be related to some residual solid and char attributed to the starch phase of the blend [45].

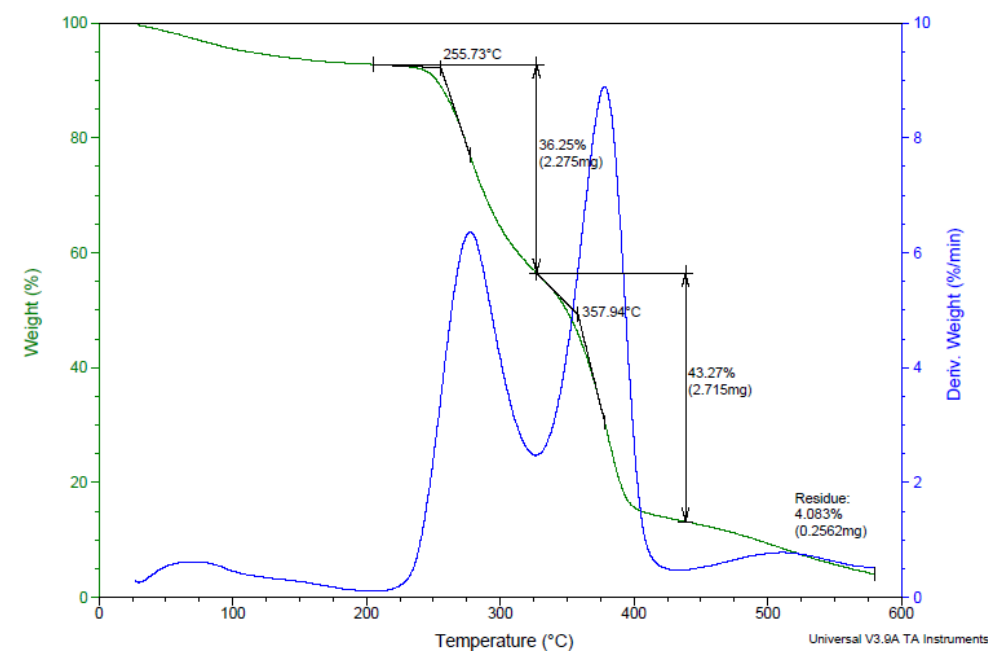

(a)

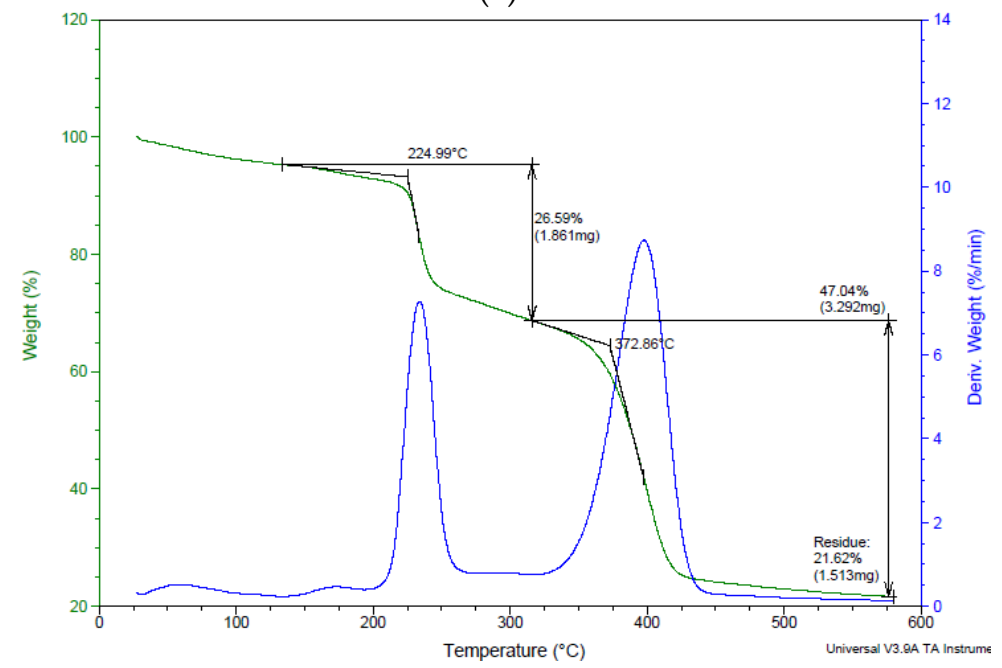

(b)

Figure 5. Cont. 


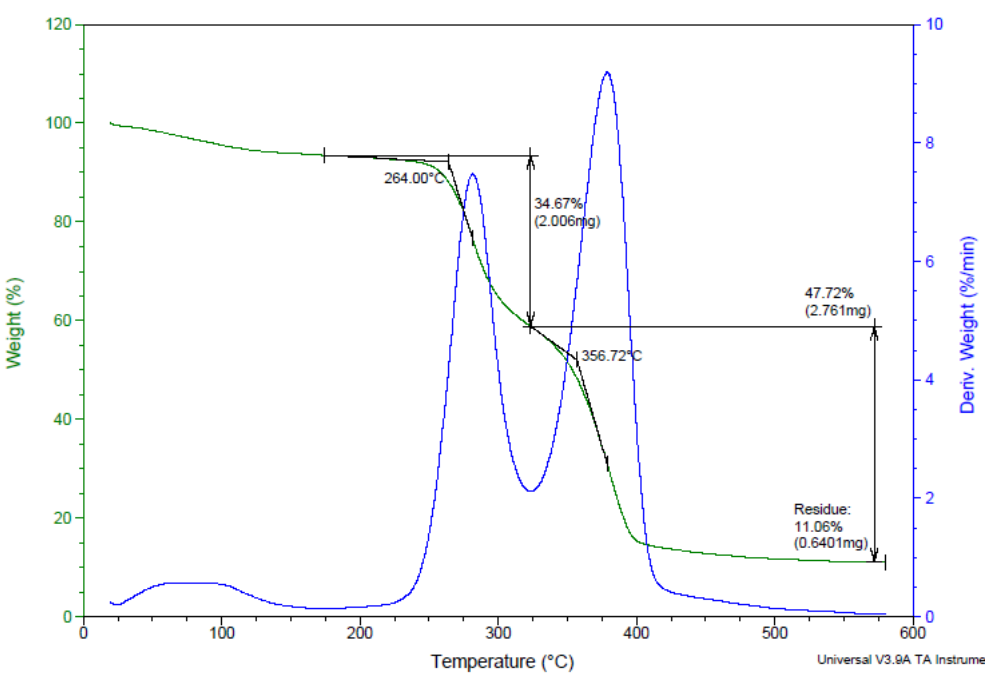

(c)

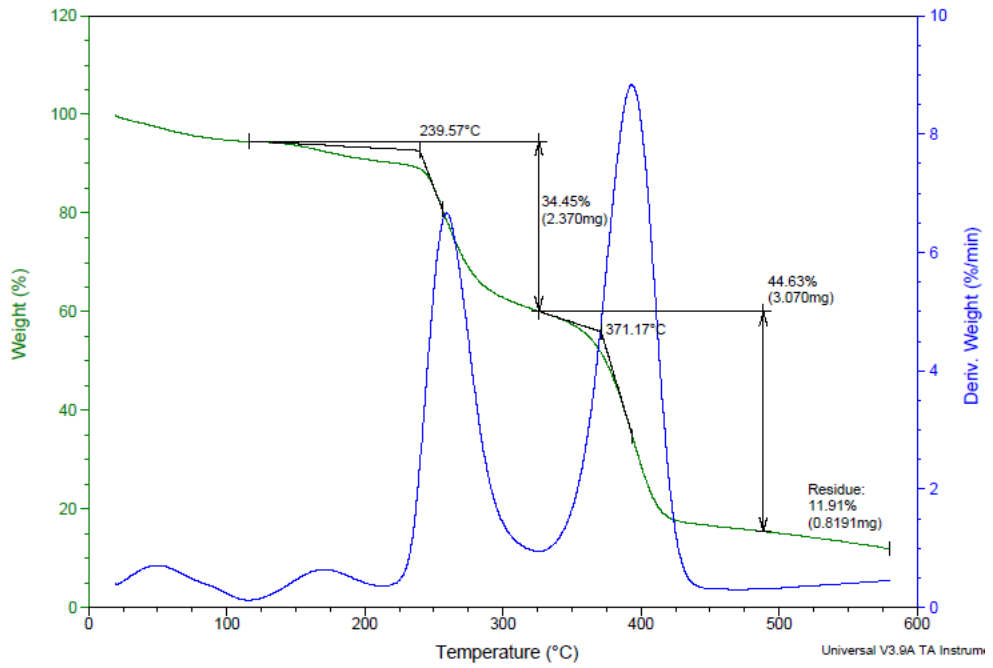

(d)

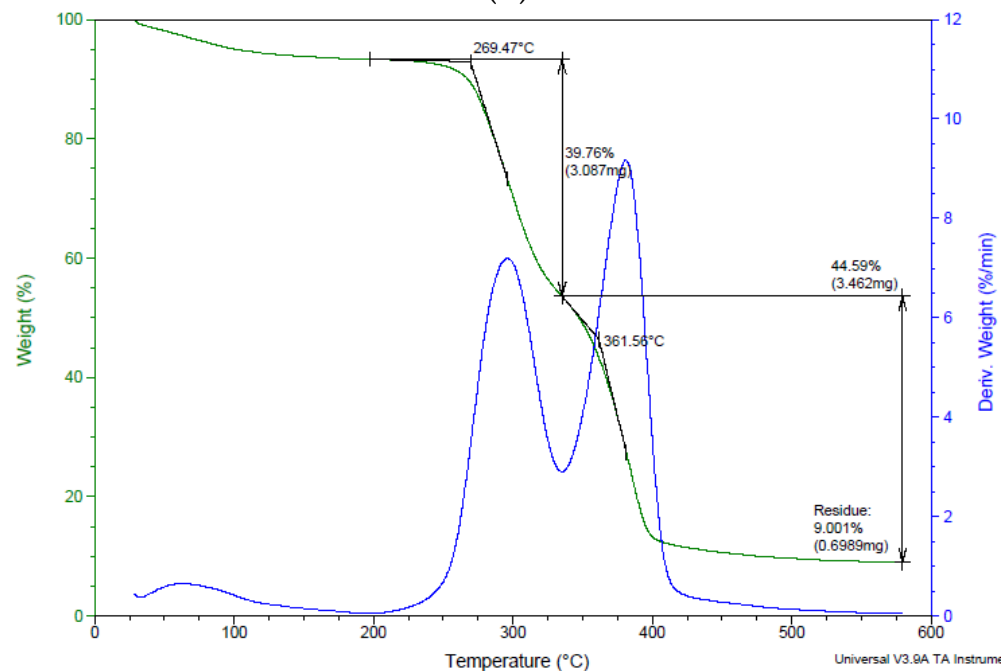

(e)

Figure 5. Analysis TGA for (a) A40; (b) B40; (c) C40; (d) D40; and (e) E40. 


\section{Conclusions}

As a conclusion, insertion of modified tapioca starch into PBS polymer blends show better strength properties and thermal stability as compared to pure starch. However, the increment of starch content in blends observed a deteriorated property for all types of starch/PBS blends. Low dispersion of starch molecules, poor interfacial bonding, and high void content are responsible for the reduction in mechanical properties. Slipped molecules found under bending loads resulted in losing flexural capabilities. FTIR results show all starch/PBS blended are found with footprints of starch, except $\mathrm{OH}$ stretching vibration, which is absent in $\mathrm{B} 40$ blends. Additionally, broad $\mathrm{O}-\mathrm{H}$ absorption in all specimens show that these are hydrogen-bonded molecules and no free $\mathrm{O}-\mathrm{H}$ bonding was found. Moreover, SEM images show good interfacial bonding between PBS and starch, except sample E40. The poor interface between starch and PBS caused an increment in void content, weakening the structure of the blends and further reducing the mechanical properties. On the other hand, a slightly weight loss found between 80 and $100{ }^{\circ} \mathrm{C}$ was due to water removal from the hydrophilic nature of starch. Furthermore, insertion of all types of starches caused lower onset temperature, but higher residual char, first onset temperature, and second thermal degradation temperature are due to starch and PBS, respectively. The objective of this study is investigating properties of starch/PBS blends. All type of blends are possible to be used in the food packaging industry. Starch A/PBS and Starch B/PBS blends are applicable on food wrap and food container materials as they have very good elongation of break and outstanding bending capability. The Starch D/PBS blend has good tensile properties and is suitable to be used for plastic grocery bags.

\section{Data Availability}

The raw / processed data required to reproduce these findings cannot be shared at this time as the data also forms part of an ongoing study.

Author Contributions: Conceptualization: R.S.A. and M.J.; methodology: R.S.A.; validation: K.Z.; data curation: K.Z.; writing—original draft preparation: R.S.A.; writing—review and editing: C.H.L.; visualization: A.K.; supervision: A.K.; project administration: A.S.H.; funding acquisition: M.J.

Funding: Malaysian Industry-Government Group for High Technology (MIGHT) for financial support of this work under Newton Engku Omar Fund grant no. 6300873.

Conflicts of Interest: The authors declare no conflicts of interest.

\section{References}

1. Karmaus, A.L.; Osborn, R.; Krishan, M. Scientific advances and challenges in safety evaluation of food packaging materials: Workshop proceedings. Regul. Toxicol. Pharmacol. 2018, 98, 80-87. [CrossRef] [PubMed]

2. Dilkes-Hoffman, L.S.; Lane, J.L.; Grant, T.; Pratt, S.; Lant, P.A.; Laycock, B. Environmental impact of biodegradable food packaging when considering food waste. J. Clean. Prod. 2018, 180, 325-334. [CrossRef]

3. Kim, S.; Yang, S.Y.; Chun, H.H.; Song, K.B. High hydrostatic pressure processing for the preparation of buckwheat and tapioca starch films. Food Hydrocoll. 2018, 81, 71-76. [CrossRef]

4. Agustin, M.B.; Ahmmad, B.; Alonzo, S.M.M.; Patriana, F.M. Bioplastic based on starch and cellulose nanocrystals from rice straw. J. Reinf. Plast. Compos. 2014, 33, 2205-2213. [CrossRef]

5. Zhou, X.-Y.; Jia, D.-M.; Cui, Y.-F.; Xie, D. Kinetics Analysis of Thermal Degradation Reaction of PVA and PVA/Starch Blends. J. Reinf. Plast. Compos. 2009, 28, 2771-2780. [CrossRef]

6. Araújo, A.; Galvão, A.; Filho, C.S.; Mendes, F.; Oliveira, M.; Barbosa, F.; Filho, M.S.; Bastos, M. Okra mucilage and corn starch bio-based film to be applied in food. Polym. Test. 2018, 71, 352-361. [CrossRef]

7. Campos, A.; Marconcini, J.; Imam, S.; Klamczynski, A.; Ortis, W.; Wood, D.; Williams, T.; Martins-Franchetti, S.; Mattoso, L. Morphological, mechanical properties and biodegradability of biocomposite thermoplastic starch and polycaprolactone reinforced with sisal fibers. J. Reinf. Plast. Compos. 2012, 31, 573-581. [CrossRef]

8. Homayouni, H.; Kavoosi, G.; Nassiri, S.M. Physicochemical, antioxidant and antibacterial properties of dispersion made from tapioca and gelatinized tapioca starch incorporated with carvacrol. LWT Food Sci. Technol. 2017, 77, 503-509. [CrossRef] 
9. Makmoon, T.; Foungfuchat, A.; Jiratumnukul, N. Modified tapioca starch as a rheology modifier in acrylic dispersion system. Prog. Org. Coat. 2013, 76, 959-962. [CrossRef]

10. Marvizadeh, M.M.; Oladzadabbasabadi, N.; Mohammadi Nafchi, A.; Jokar, M. Preparation and characterization of bionanocomposite film based on tapioca starch/bovine gelatin/nanorod zinc oxide. Int. J. Boil. Macromol. 2017, 99, 1-7. [CrossRef] [PubMed]

11. Peelman, N.; Ragaert, P.; De Meulenaer, B.; Adons, D.; Peeters, R.; Cardon, L.; Van Impe, F.; Devlieghere, F. Application of bioplastics for food packaging. Trends Food Sci. Technol. 2013, 32, 128-141. [CrossRef]

12. Jabeen, N.; Majid, I.; Nayik, G.A. Bioplastics and food packaging: A review. Cogent Food Agric. 2015, 1, 1117749. [CrossRef]

13. Bautista, M.; Martínez De Ilarduya, A.; Alla, A.; Vives, M.; Morató, J.; Muñoz-Guerra, S. Cationic poly(butylene succinate) copolyesters. Eur. Polym. J. 2016, 75, 329-342. [CrossRef]

14. Lancuški, A.; Abu Ammar, A.; Avrahami, R.; Vilensky, R.; Vasilyev, G.; Zussman, E. Design of starch-formate compound fibers as encapsulation platform for biotherapeutics. Carbohydr. Polym. 2017, 158, 68-76. [CrossRef] [PubMed]

15. Lee, C.H.; Sapuan, S.M.; Lee, J.H.; Hassan, M.R. Mechanical properties of kenaf fibre reinforced floreon biocomposites with magnesium hydroxide filler. J. Mech. Eng. Sci. 2016, 10, 2234-2248. [CrossRef]

16. Maubane, L.; Ray, S.S.; Jalama, K. The effect of starch amylose content on the morphology and properties of melt-processed butyl-etherified starch/poly[(butylene succinate)-co-adipate] blends. Carbohydr. Polym. 2017, 155, 89-100. [CrossRef] [PubMed]

17. Oliveira, T.A.; Oliveira, R.R.; Barbosa, R.; Azevedo, J.B.; Alves, T.S. Effect of reprocessing cycles on the degradation of PP/PBAT-thermoplastic starch blends. Carbohydr. Polym. 2017, 168, 52-60. [CrossRef] [PubMed]

18. Patel, H.; Royall, P.G.; Gaisford, S.; Williams, G.R.; Edwards, C.H.; Warren, F.J.; Flanagan, B.M.; Ellis, P.R.; Butterworth, P.J. Structural and enzyme kinetic studies of retrograded starch: Inhibition of $\alpha$-amylase and consequences for intestinal digestion of starch. Carbohydr. Polym. 2017, 164, 154-161. [CrossRef] [PubMed]

19. Frollini, E.; Bartolucci, N.; Sisti, L.; Celli, A. Biocomposites based on poly(butylene succinate) and curaua: Mechanical and morphological properties. Polym. Test. 2015, 45, 168-173. [CrossRef]

20. Negrin, M.; Macerata, E.; Consolati, G.; Quasso, F.; Genovese, L.; Soccio, M.; Giola, M.; Lotti, N.; Munari, A.; Mariani, M. Gamma radiation effects on random copolymers based on poly(butylene succinate) for packaging applications. Radiat. Phys. Chem. 2018, 142, 34-43. [CrossRef]

21. Georgousopoulou, I.N.; Vouyiouka, S.; Dole, P.; Papaspyrides, C.D. Thermo-mechanical degradation and stabilization of poly(butylene succinate). Polym. Degrad. Stab. 2016, 128, 182-192. [CrossRef]

22. Li, J.; Luo, X.; Lin, X.; Zhou, Y. Comparative study on the blends of PBS/thermoplastic starch prepared from waxy and normal corn starches. Starch/Staerke 2013, 65, 831-839. [CrossRef]

23. Suttiruengwong, S.; Sotho, K.; Seadan, M. Effect of Glycerol and Reactive Compatibilizers on Poly(butylene succinate)/Starch Blends. J. Renew. Mater. 2014, 2, 85-92. [CrossRef]

24. Wang, W.; Zhang, G.; Zhang, W.; Guo, W.; Wang, J. Processing and Thermal Behaviors of Poly(Butylene Succinate) Blends with Highly-Filled Starch and Glycerol. J. Polym. Environ. 2013, 21, 46-53. [CrossRef]

25. Jamaluddin, N.; Razaina, M.T.; Ishak, Z.A.M. Mechanical and Morphology Behaviours of Polybutylene (succinate)/Thermoplastic Polyurethaneblend. Procedia Chem. 2016, 19, 426-432. [CrossRef]

26. Liu, L.; Yu, J.; Cheng, L.; Qu, W. Mechanical properties of poly(butylene succinate) (PBS) biocomposites reinforced with surface modified jute fibre. Compos. Part A 2009, 40, 669-674. [CrossRef]

27. Lu, Y.; Wu, C.; Xu, S. Mechanical, thermal and flame retardant properties of magnesium hydroxide filled poly(vinyl chloride) composites: The effect of filler shape. Compos. Part A 2018, 113, 1-11. [CrossRef]

28. Santagata, G.; Valerio, F.; Cimmino, A.; Dal Poggetto, G.; Masi, M.; Di Biase, M.; Malinconico, M.; Lavermicocca, P.; Evidente, A. Chemico-physical and antifungal properties of poly(butylene succinate)/ cavoxin blend: Study of a novel bioactive polymeric based system. Eur. Polym. J. 2017, 94, 230-247. [CrossRef]

29. Lu, Z.-H.; Donner, E.; Yada, R.Y.; Liu, Q. Physicochemical properties and in vitro starch digestibility of potato starch/protein blends. Carbohydr. Polym. 2016, 154, 214-222. [CrossRef] [PubMed]

30. Khatoon, S.; Sreerama, Y.N.; Raghavendra, D.; Bhattacharya, S.; Bhat, K.K. Properties of enzyme modified corn, rice and tapioca starches. Food Res. Int. 2009, 42, 1426-1433. [CrossRef] 
31. Whitney, K.; Reuhs, B.L.; Ovando Martinez, M.; Simsek, S. Analysis of octenylsuccinate rice and tapioca starches: Distribution of octenylsuccinic anhydride groups in starch granules. Food Chem. 2016, 211, 608-615. [CrossRef] [PubMed]

32. Shi, K.; Liu, Y.; Hu, X.; Su, T.; Li, P.; Wang, Z. Preparation, characterization, and biodegradation of poly(butylene succinate)/cellulose triacetate blends. Int. J. Boil. Macromol. 2018, 114, 373-380. [CrossRef] [PubMed]

33. Espinel Villacrés, R.A.; Flores, S.K.; Gerschenson, L.N. Biopolymeric antimicrobial films: Study of the influence of hydroxypropyl methylcellulose, tapioca starch and glycerol contents on physical properties. Mater. Sci. Eng. C 2014, 36, 108-117. [CrossRef] [PubMed]

34. Monroy, Y.; Rivero, S.; García, M.A. Microstructural and techno-functional properties of cassava starch modified by ultrasound. Ultrason. Sonochem. 2018, 42, 795-804. [CrossRef] [PubMed]

35. Breuninger, W.F.; Piyachomkwan, K.; Sriroth, K. Tapioca/Cassava Starch: Production and Use. In Starch; Elsevier: Amsterdam, The Netherlands, 2009; pp. 541-568.

36. Gao, J.; Vasanthan, T.; Hoover, R.; Li, J. Structural modification of waxy, regular, and high-amylose maize and hulless barley starches on partial acid hydrolysis and their impact on physicochemical properties and chemical modification. Starch/Staerke 2012, 64, 313-325. [CrossRef]

37. Wang, N.; Yu, J.; Chang, P.R.; Ma, X. Influence of formamide and water on the properties of thermoplastic starch/poly(lactic acid) blends. Carbohydr. Polym. 2008, 71, 109-118. [CrossRef]

38. De Paiva, J.M.F.; Frollini, E. Unmodified and modified surface sisal fibers as reinforcement of phenolic and lignophenolic matrices composites: Thermal analyses of fibers and composites. Macromol. Mater. Eng. 2006, 291, 405-417. [CrossRef]

39. Lee, C.H.; Sapuan, S.M.; Hassan, M.R. Thermal analysis of kenaf fiber reinforced floreon biocomposites with magnesium hydroxide flame retardant filler. Polym. Compos. 2018, 39, 869-875. [CrossRef]

40. Liminana, P.; Garcia-Sanoguera, D.; Quiles-Carrillo, L.; Balart, R.; Montanes, N. Development and characterization of environmentally friendly composites from poly(butylene succinate) (PBS) and almond shell flour with different compatibilizers. Compos. Part B 2018, 144, 153-162. [CrossRef]

41. Tian, Y.; Li, Y.; Xu, X.; Jin, Z. Starch retrogradation studied by thermogravimetric analysis (TGA). Carbohydr. Polym. 2011, 84, 1165-1168. [CrossRef]

42. Sánchez-Jiménez, P.E.; Pérez-Maqueda, L.A.; Perejón, A.; Criado, J.M. Generalized master plots as a straightforward approach for determining the kinetic model: The case of cellulose pyrolysis. Thermochim. Acta 2013, 552, 54-59. [CrossRef]

43. Sánchez-Jiménez, P.E.; Pérez-Maqueda, L.A.; Perejón, A.; Pascual-Cosp, J.; Benítez-Guerrero, M.; Criado, J.M. An improved model for the kinetic description of the thermal degradation of cellulose. Cellulose 2011, 18, 1487-1498. [CrossRef]

44. Colussi, R.; Pinto, V.Z.; El Halal, S.L.M.; Vanier, N.L.; Villanova, F.A.; Marques e Silva, R.; da Rosa Zavareze, E.; Dias, A.R.G. Structural, morphological, and physicochemical properties of acetylated high-, medium-, and low-amylose rice starches. Carbohydr. Polym. 2014, 103, 405-413. [CrossRef] [PubMed]

45. Boonprasith, P.; Wootthikanokkhan, J.; Nimitsiriwat, N. Mechanical, thermal, and barrier properties of nanocomposites based on poly(butylene succinate)/thermoplastic starch blends containing different types of clay. J. Appl. Polym. Sci. 2013, 130, 1114-1123. [CrossRef]

(C) 2018 by the authors. Licensee MDPI, Basel, Switzerland. This article is an open access article distributed under the terms and conditions of the Creative Commons Attribution (CC BY) license (http://creativecommons.org/licenses/by/4.0/). 